\title{
The relation of total body potassium to height, weight, and age in normal adults
}

\author{
K. BODDY, PRISCILLA C. KING, R. HUME, AND ELSPETH WEYERS
}

From the Scottish Research Reactor Centre, East Kilbride, and the Department of Medicine, Southern General Hospital, Glasgow

SYNOPSIS Total body potassium was measured in 103 healthy adults using a shadow-shield wholebody monitor of high sensitivity. The range of height was 147 to $192 \mathrm{~cm}$, of weight 43 to $92 \mathrm{~kg}$, and of age 18 to 77 years.

The values obtained for total body potassium were correlated with height, with weight, and with height and weight. Age was then included as an additional variable.

The standard deviation from regression was smaller when total body potassium was correlated 윽 with height than with weight and was further reduced, to about $9 \%$, in a multiple regression using height and age. The advantages of this relationship over indices involving weight are discussed.

The smallest standard deviation from regression, $7 \cdot 5 \%$, was obtained when total body potassium was correlated with height, weight, and age. The usefulness of this relationship is discussed with comment on its limitations.

A regression equation was derived between lean body mass (derived from height and weight) and total body potassium with a standard deviation from regression of $5.5 \%$ in males and $7 \cdot 3 \%$ in females.

The importance of potassium as a body electrolyte is well established but the only method of directly measuring the total body content of this mineral is by use of highly sensitive whole-body radioactivity monitors. An advantage of this technique is that a single measurement only is required, so that results are obtained rapidly and with minimum inconvenience to the patient. When the monitor has been calibrated, the need to administer radioactive isotopes is obviated.

In studying changes in body potassium due to treatment or disease, control values may be obtained before treatment or after recovery. Expressing the difference as a percentage change is adequate in some investigations. However, in certain clinical disorders it may be highly desirable to know at a time when no control values are available whether the total body potassium differs from that in normal control subjects and if so to what extent. Total body potassium per unit body weight (m-equiv/kg BW) $(\mathrm{mmol} / \mathrm{kg}$ ) has been used previously as an index but the dependency on body weight only limits its usefulness because of the effect of obesity, oedema, and starvation.

Correspondence: Dr Keith Boddy, Scottish Research Reactor Centre, East Kilbride, Glasgow.

Received for publication 20 January 1972.
Expression of total body potassium in relation to $\overrightarrow{\overrightarrow{0}}$ lean body mass (m-equiv/kg LBM) (mmol/kg) largely avoids this problem but in practice is not clinically convenient because the estimation of lean body mass by density or by dilution techniques involves delay, expense in terms of money and man power, and further disturbance of the patient. It has been shown, however, that lean body mass can be estimated with acceptable accuracy in adults from the height and weight of the subject (Hume, 1966; Hume and Weyers, 1971). Since the subject's height is not usually affected by the same factors as those influencing body weight, the possibility that total body potassium was significantly related to height as $N$ well as weight merited investigation. The relation- $N$ ships between total body potassium and lean body mass also deserved further study.

\section{Materials and Methods}

The study included 103 healthy control subjects $(49 \stackrel{+}{+}$ males and 54 females). All were on a normal diet and $\frac{0}{0}$ fluid intake. The subjects ranged in weight from $43.1 \stackrel{\vec{D}}{\circ}$ to $93 \cdot 3 \mathrm{~kg}$, in height from $147 \cdot 3$ to $191 \cdot 8 \mathrm{~cm}$, and in $\frac{\stackrel{\rho}{\mathbb{Q}}}{\stackrel{\circ}{2}}$
age from 18 to 77 years (Table I).

Although it would have been advantageous if 


\begin{tabular}{|c|c|c|c|c|c|c|}
\hline Subject & Age & $\begin{array}{l}\text { Weight } \\
(\mathrm{kg})\end{array}$ & $\begin{array}{l}\text { Height } \\
(\mathrm{cm})\end{array}$ & $\begin{array}{l}\text { Lean Body Mass } \\
(L B M)(k g)\end{array}$ & $\begin{array}{l}\text { Potassium } \\
\text { (m-equiv) }\end{array}$ & $\begin{array}{l}\text { Potassium } \\
\text { (m-equiv/kg LBM) }\end{array}$ \\
\hline \multicolumn{7}{|l|}{ Males } \\
\hline 1 & 54 & 70.0 & $156 \cdot 2$ & 51.0 & 2928 & $57 \cdot 4$ \\
\hline 2 & 20 & $57 \cdot 3$ & 171.5 & $49 \cdot 7$ & 3064 & $61 \cdot 6$ \\
\hline 3 & 24 & $72 \cdot 8$ & 177.8 & 57.9 & 4281 & 73.9 \\
\hline 4 & 30 & 53.0 & 166.4 & $46 \cdot 8$ & 2793 & 59.7 \\
\hline 5 & 30 & 75.0 & $174 \cdot 0$ & $57 \cdot 7$ & 3808 & 66.0 \\
\hline 6 & 44 & $54 \cdot 0$ & $17 J \cdot 2$ & $48 \cdot 2$ & 2974 & $61 \cdot 7$ \\
\hline 7 & 30 & 62.0 & $177 \cdot 8$ & $53 \cdot 5$ & 3893 & $72 \cdot 8$ \\
\hline 8 & 34 & 74.0 & 167.6 & $55 \cdot 6$ & 3826 & $68 \cdot 8$ \\
\hline 9 & 26 & 64.0 & $181 \cdot 6$ & $55 \cdot 3$ & 4228 & 76.5 \\
\hline 10 & 26 & 56.7 & 161.9 & $47 \cdot 1$ & 2757 & $58 \cdot 5$ \\
\hline 11 & 58 & $55 \cdot 3$ & $171 \cdot 5$ & $49 \cdot 1$ & 2852 & $58 \cdot 1$ \\
\hline 12 & 25 & 68.0 & 172.7 & $54 \cdot 5$ & 3703 & $68 \cdot 0$ \\
\hline 13 & 25 & 80.7 & 175.3 & 60.4 & 4345 & 71.9 \\
\hline 14 & 24 & $58 \cdot 6$ & 179.1 & 52.4 & 3593 & $68 \cdot 6$ \\
\hline 15 & 24 & 60.9 & 174.0 & 52.0 & 3703 & $71 \cdot 2$ \\
\hline 16 & 24 & $68 \cdot 0$ & 179.1 & $56 \cdot 2$ & 3660 & $65 \cdot 1$ \\
\hline 17 & 24 & 69.0 & $180 \cdot 3$ & 57.0 & 4177 & $73 \cdot 3$ \\
\hline 18 & 25 & $83 \cdot 5$ & 184.2 & $63 \cdot 2$ & 4795 & 75.9 \\
\hline 19 & 23 & 78.9 & $170 \cdot 2$ & $58 \cdot 3$ & 3903 & 66.9 \\
\hline 20 & 43 & 59.0 & 157.5 & $46 \cdot 8$ & 2499 & 53.4 \\
\hline 21 & 51 & $61 \cdot 7$ & $160 \cdot 7$ & 48.8 & 2680 & 54.9 \\
\hline 22 & 46 & $67 \cdot 6$ & $170 \cdot 2$ & $53 \cdot 7$ & 3478 & $64 \cdot 8$ \\
\hline 23 & 43 & $78 \cdot 5$ & 174.0 & $59 \cdot 2$ & 3747 & $63 \cdot 3$ \\
\hline 24 & 22 & 52.0 & $170 \cdot 8$ & $47 \cdot 5$ & 3315 & 69.8 \\
\hline 25 & 77 & $47 \cdot 2$ & $157 \cdot 5$ & 42.0 & 2320 & $55 \cdot 2$ \\
\hline 26 & 31 & 80.7 & 175.5 & $60 \cdot 5$ & 4274 & 70.6 \\
\hline 27 & 35 & 74.5 & 177.8 & $58 \cdot 5$ & 3440 & $58 \cdot 8$ \\
\hline 28 & 35 & $70 \cdot 5$ & 176.5 & $56 \cdot 6$ & 3366 & 59.5 \\
\hline 29 & 27 & $69 \cdot 4$ & $171 \cdot 5$ & $54 \cdot 8$ & 3072 & $56 \cdot 1$ \\
\hline 30 & 64 & 73.9 & $170 \cdot 2$ & $56 \cdot 3$ & 3174 & 56.4 \\
\hline 31 & 58 & $54 \cdot 4$ & $151 \cdot 1$ & $43 \cdot 2$ & 2253 & $52 \cdot 2$ \\
\hline 32 & 65 & $62 \cdot 1$ & $171 \cdot 5$ & 51.8 & 2757 & $53 \cdot 2$ \\
\hline 33 & 43 & 81.7 & $177 \cdot 8$ & $61 \cdot 5$ & 4049 & $65 \cdot \overline{8}$ \\
\hline 34 & 47 & $71 \cdot 7$ & $177 \cdot 8$ & $57 \cdot 4$ & 3460 & $60 \cdot 3$ \\
\hline 35 & 43 & $75 \cdot 3$ & 184.2 & $60 \cdot 6$ & 4107 & 67.8 \\
\hline 36 & 43 & 80.7 & 172.7 & 59.7 & 3373 & 56.5 \\
\hline 37 & 42 & 60.5 & 170.2 & 50.8 & 3171 & $62 \cdot 4$ \\
\hline 38 & 25 & 69.5 & $177 \cdot 8$ & 56.7 & 3312 & $58 \cdot 4$ \\
\hline 39 & 28 & $72 \cdot 7$ & 182.9 & $59 \cdot 3$ & 3921 & $66 \cdot 1$ \\
\hline 40 & 26 & 65.9 & 177.8 & $55 \cdot 1$ & 4013 & $72 \cdot 8$ \\
\hline 41 & 38 & $61 \cdot 8$ & 167.6 & 50.9 & 3233 & $63 \cdot 5$ \\
\hline 42 & 24 & 60.0 & 172.7 & $51 \cdot 3$ & 3368 & 65.7 \\
\hline 43 & 23 & 85.4 & 191.8 & $66 \cdot 5$ & 4417 & $66 \cdot 4$ \\
\hline 44 & 46 & $92 \cdot 3$ & 171.5 & $63 \cdot 6$ & 3668 & $57 \cdot 7$ \\
\hline 45 & 26 & 65.4 & 174.0 & $53 \cdot 7$ & 3333 & $62 \cdot 1$ \\
\hline 46 & 21 & $63 \cdot 5$ & 177.8 & $54 \cdot 1$ & 3880 & $71 \cdot 7$ \\
\hline 47 & 20 & 69.9 & 175.3 & 56.0 & 4143 & $74 \cdot 0$ \\
\hline 48 & 21 & 78.0 & $181 \cdot 6$ & $61 \cdot 0$ & 4422 & $72 \cdot 5$ \\
\hline 49 & 22 & $65 \cdot 3$ & $167 \cdot 6$ & $51 \cdot 3$ & 3345 & $65 \cdot 2$ \\
\hline Mean & 35 & $68 \cdot 0$ & $173 \cdot 2$ & $54 \cdot 6$ & 3532 & $64 \cdot 7$ \\
\hline \multicolumn{7}{|l|}{ Females } \\
\hline 50 & 23 & $62 \cdot 4$ & 169.0 & $47 \cdot 2$ & 2742 & $58 \cdot 1$ \\
\hline 51 & 29 & $57 \cdot 0$ & $161 \cdot 3$ & $42 \cdot 2$ & 2563 & 60.7 \\
\hline 52 & 23 & 54.0 & 163.8 & $42 \cdot 6$ & 2849 & 66.9 \\
\hline 53 & 23 & $45 \cdot 4$ & $156 \cdot 2$ & 36.9 & 2223 & $60 \cdot 2$ \\
\hline
\end{tabular}

Table I Total body potassium together with relevant physiological data

children had been included in the present study, this would have necessitated administering radioactive isotopes to healthy children which was considered ethically undesirable.

Total body potassium was measured using the Merlin mobile whole-body monitor (Boddy, 1967) with a NaI detector $29.2 \mathrm{~cm}$ diameter by $10.2 \mathrm{~cm}$ deep. A shadow-shield of $10 \mathrm{~cm}$ thick lead bricks, a total weight of less than $8000 \mathrm{~kg}$, surrounded the detector housed in a central turret. The patient, lying supine on a motorized couch, passed beneath the detector and was scanned from head to feet. The output was taken to a TMC 400-channel pulse height analyser. After printout of the accumulated data, the patient adopted the prone position, the direction of travel of the couch was reversed and the patient was scanned from feet to head. The data were again recorded and mean values were obtained for the 


\begin{tabular}{|c|c|c|c|c|c|c|}
\hline Subject & Age & $\begin{array}{l}\text { Weight } \\
(\mathrm{kg})\end{array}$ & $\begin{array}{l}\text { Height } \\
(\mathrm{cm})\end{array}$ & $\begin{array}{l}\text { Lean Body Mass } \\
(L B M)(k g)\end{array}$ & $\begin{array}{l}\text { Potassium } \\
\text { (m-equiv) }\end{array}$ & $\begin{array}{l}\text { Potassium } \\
\text { (m-equiv/kg LBM) }\end{array}$ \\
\hline 54 & 24 & $60 \cdot 8$ & 160.0 & 42.5 & 2563 & $60 \cdot 3$ \\
\hline 55 & 22 & $69 \cdot 8$ & 166.4 & $47 \cdot 8$ & 2711 & 56.7 \\
\hline 56 & 23 & 60.0 & $161 \cdot 3$ & 42.9 & 2593 & 60.5 \\
\hline 57 & 25 & 50.8 & $165 \cdot 1$ & 42.4 & 2673 & 63.0 \\
\hline 58 & 70 & 54.4 & 154.9 & 38.5 & 1995 & 51.8 \\
\hline 59 & 38 & 63.0 & 160.0 & $43 \cdot 1$ & 2445 & 56.7 \\
\hline 60 & 23 & $44 \cdot 1$ & 152.4 & $34 \cdot 7$ & 2064 & $59 \cdot 5$ \\
\hline 61 & 25 & 49.4 & 158.8 & $39 \cdot 1$ & 2146 & 54.9 \\
\hline 62 & 23 & $60 \cdot 3$ & 168.9 & 46.6 & 2685 & 57.6 \\
\hline 63 & 23 & 69.9 & $172 \cdot 7$ & 50.8 & 3202 & 63.0 \\
\hline 64 & 23 & 51.0 & 157.5 & 38.9 & 2350 & 60.4 \\
\hline 65 & 23 & $52 \cdot 2$ & 162.6 & $41 \cdot 6$ & 2310 & $55 \cdot 5$ \\
\hline 65 & 53 & $48 \cdot 1$ & 157.5 & $38 \cdot 1$ & 2123 & $55 \cdot 7$ \\
\hline 67 & 24 & $48 \cdot 5$ & $165 \cdot 1$ & $41 \cdot 8$ & 2473 & $59 \cdot 2$ \\
\hline 68 & 23 & $53 \cdot 1$ & 154.9 & $38 \cdot 2$ & 2483 & 65.0 \\
\hline 69 & 24 & 53.5 & $161 \cdot 3$ & $41 \cdot 3$ & 2187 & 53.0 \\
\hline 70 & 24 & 64.9 & 167.6 & $47 \cdot 1$ & 2624 & 55.7 \\
\hline 71 & 20 & $64 \cdot 0$ & 162.6 & $44 \cdot 6$ & 3084 & $69 \cdot 2$ \\
\hline 72 & 37 & 60.8 & $165 \cdot 1$ & 44.9 & 2489 & 55.4 \\
\hline 73 & 29 & $62 \cdot 8$ & $165 \cdot 1$ & $45 \cdot 4$ & 2361 & 52.0 \\
\hline 74 & 24 & 88.0 & 168.9 & 53.6 & 2778 & 51.8 \\
\hline 75 & 42 & $62 \cdot 1$ & $165 \cdot 1$ & $45 \cdot 3$ & 2276 & 50.2 \\
\hline 76 & 24 & 52.6 & 163.8 & $42 \cdot 3$ & 2018 & $47 \cdot \overline{7}$ \\
\hline 77 & 25 & $76 \cdot 7$ & 182.9 & $57 \cdot 3$ & 3443 & $60 \cdot 1$ \\
\hline 78 & 59 & 57.0 & 157.5 & 40.4 & 2084 & 51.6 \\
\hline 79 & 38 & $61 \cdot 2$ & $161 \cdot 3$ & $43 \cdot 2$ & 2463 & 57.0 \\
\hline 80 & 21 & 55.4 & 160.0 & $41 \cdot 2$ & 2555 & 62.0 \\
\hline 81 & 58 & $56 \cdot 3$ & $151 \cdot 1$ & 37.2 & 1972 & 53.0 \\
\hline 82 & 42 & $65 \cdot 3$ & $147 \cdot 3$ & 37.7 & 2302 & $61 \cdot 1$ \\
\hline 83 & 62 & $65 \cdot 3$ & 157.5 & $42 \cdot 5$ & 2202 & $51 \cdot 8$ \\
\hline 84 & 48 & 49.9 & 162.6 & 41.0 & 2056 & $50 \cdot 1$ \\
\hline 85 & 41 & 50.3 & 157.5 & $38 \cdot 7$ & 2082 & $53 \cdot 8$ \\
\hline 86 & 60 & 54.0 & 153.7 & $37 \cdot 8$ & 2087 & $55 \cdot 2$ \\
\hline 87 & 49 & $68 \cdot 5$ & 156.2 & $42 \cdot 7$ & 2381 & $55 \cdot 8$ \\
\hline 88 & 57 & $66 \cdot 2$ & $172 \cdot 7$ & 49.9 & 2476 & $49 \cdot 6$ \\
\hline 89 & 60 & 64.0 & $161 \cdot 3$ & 43.9 & 2079 & $47 \cdot 4$ \\
\hline 90 & 60 & 62.6 & $172 \cdot 7$ & 49.0 & 2315 & $47 \cdot 2$ \\
\hline 91 & 65 & 64.0 & $166 \cdot 4$ & $46 \cdot 4$ & 2458 & 53.0 \\
\hline 92 & 68 & $62 \cdot 1$ & $156 \cdot 2$ & $41 \cdot 1$ & 2033 & $49 \cdot 5$ \\
\hline 93 & 72 & $47 \cdot 2$ & 160.0 & $39 \cdot 1$ & 2018 & $51 \cdot 6$ \\
\hline 94 & 49 & $43 \cdot \overline{1}$ & 148.6 & $32 \cdot 7$ & 2005 & $61 \cdot 3$ \\
\hline 95 & 21 & $62 \cdot 8$ & 168.9 & $47 \cdot 2$ & 2742 & $58 \cdot 1$ \\
\hline 96 & 34 & 55.0 & $167 \cdot 6$ & $44 \cdot 8$ & 2601 & $58 \cdot 1$ \\
\hline 97 & 18 & $49 \cdot 5$ & 163.8 & 41.7 & 2652 & $63 \cdot 6$ \\
\hline 98 & 24 & $61 \cdot 7$ & 171.5 & $48 \cdot 2$ & 2982 & 61.9 \\
\hline 99 & 19 & $48 \cdot 5$ & $156 \cdot 2$ & 37.6 & 2425 & $64 \cdot 5$ \\
\hline 100 & 18 & $57 \cdot 2$ & 160.0 & 42.0 & 2289 & 54.5 \\
\hline 101 & 28 & $69 . \overline{9}$ & $171 \cdot 5$ & $50 \cdot 2$ & 3358 & 66.9 \\
\hline 102 & 41 & $73 \cdot 5$ & 171.5 & $51 \cdot 1$ & 3166 & 62.0 \\
\hline 103 & 30 & $61 \cdot 7$ & 167.6 & 45.6 & 2552 & 56.0 \\
\hline Mean & 36 & $58 \cdot 7$ & 162.4 & $43 \cdot 2$ & 2460 & 56.9 \\
\hline
\end{tabular}

Table 1 continued

two positions. The sensitivity obtained was at least comparable with that of the conventional steel or lead room monitors. The subject counting rate in the potassium-40 photopeak $(1 \cdot 36-1 \cdot 56 \mathrm{Mev})$ was expressed as m-equiv (mmol of potassium without the administration of a radioactive isotope, using the procedure described in detail elsewhere(Boddy, King, Tothill, and Strong, 1971). The estimated coefficient of variation of this procedure was shown to be $\pm 3.9 \%$ for a subject having $3600 \mathrm{~m}$-equiv $(\mathrm{mmol}) \mathrm{K}$.

Total body water (TBW) and lean body mass (LBM) were calculated from the weight (W) and height $(\mathrm{H})$ of each subject according to the formulae of Hume and Weyers (1971). The relationships were as follows:

Males: $\quad$ TBW (litres) $=0.2968 \mathrm{~W}(\mathrm{~kg})+$

$$
0 \cdot 1948 \mathrm{H}(\mathrm{cm})-14.0129
$$

Females: TBW (litres) $=0 \cdot 1838 \mathrm{~W}(\mathrm{~kg})+$

$$
0 \cdot 3446 \mathrm{H}(\mathrm{cm})-35 \cdot 2701
$$

where

$\operatorname{LBM}(\mathrm{kg})=\mathrm{TBW} \times \frac{100}{73}($ Pace and Rathbun, 1945).

Results

Relevant physiological data for each subject are 


\begin{tabular}{|c|c|c|c|c|}
\hline \multirow[t]{2}{*}{ Independent Variables } & \multicolumn{2}{|c|}{ Correlation Coefficient } & \multicolumn{2}{|c|}{$\begin{array}{l}\text { Standard Deviation from Regression } \\
(\%)\end{array}$} \\
\hline & Males & Females & Males & Females \\
\hline $\begin{array}{l}\text { Height } \\
\text { Weight } \\
\text { Height and weight } \\
\text { Height and age } \\
\text { Height, weight, and age }\end{array}$ & $\begin{array}{l}0.818 \\
0 \cdot 688 \\
0 \cdot 875 \\
0.841 \\
0.907\end{array}$ & $\begin{array}{l}0.732 \\
0.594 \\
0.765 \\
0.806 \\
0.875\end{array}$ & $\begin{array}{r}9 \cdot 7 \\
12 \cdot 3 \\
8 \cdot 3 \\
9 \cdot 3 \\
7 \cdot 3\end{array}$ & $\begin{array}{r}10 \cdot 1 \\
11.9 \\
9.6 \\
8 \cdot 8 \\
7.8\end{array}$ \\
\hline
\end{tabular}

Table II Correlation of total body potassium with height, weight, and age

summarized in Table I. The values obtained for total body potassium are given in the same table together with the calculated lean body mass.

The linear regressions of total body potassium on height and on weight were computed by the method of least squares. A multiple regression on height and weight was then calculated and finally age was included as an additional variable. These results are summarized in Table II, which shows correlation coefficients and standard deviations from regression. The correlation was highly significant in each case. The relationships of particular interest and potential importance are

(a) Total body potassium on height and age:

Males: m-equiv $\mathrm{K}(\mathrm{mmol} \mathrm{K})=53.02 \mathrm{H}-9.74$ Age $-5305$

Females: m-equivK $(\mathrm{mmol} \mathrm{K})=33.63 \mathrm{H}-7.73$ Age $-2727$

(b) Total body potassium on height, weight, and age:

Males: m-equiv $\mathrm{K}(\mathrm{mmol} \mathrm{K})=23.96 \mathrm{~W}+35.15 \mathrm{H}$ - 12.09 Age - 3762

Females: m-equiv $\mathrm{K}(\mathrm{mmol} \mathrm{K})=14.76 \mathrm{~W}+22.07 \mathrm{H}$ - 9.05 Age - 1669

The linear regression of calculated lean body mass on total body potassium was also computed. The relationships obtained were:

Males: $\quad$ LBM $(\mathrm{kg})=7.550 \times 10^{-3}$ m-equiv K $+27 \cdot 98$

Females: $\mathrm{LBM}(\mathrm{kg})=1.014 \times 10^{-2}$ m-equiv $\mathrm{K}$ $+18 \cdot 23$

which were highly significant $(r=0.83$ and 0.76 respectively) with a standard deviation from regression of 5.5 and $7.3 \%$ of the mean respectively.

\section{Discussion}

Total body potassium can be measured conveniently by a whole-body monitor without the administration of a radioactive isotope. In some clinical circumstances, however, it is not sufficient to know the total body potassium of a patient without reference to the 'normal' value or range of body potassium for that individual. The most sensitive index of 'normality' will have the smallest range and therefore give better resolution between 'normal' and 'abnormal' values for total body potassium. However, if the index involves a reference to some physical characteristic such as body weight, for example in m-equiv $\mathrm{K} / \mathrm{kg} \mathrm{BW}$ $(\mathrm{mmol} \mathrm{K} / \mathrm{kg} \mathrm{BW})$, then the index must not be invalidated as a result of variation in the reference characteristic.

In normal males and females total body potassium varies so widely with body habitus and with age (Table I) that reference to some physical characteristic is essential to provide a more definitive index. Previously, total body potassium has been related to body weight (m-equiv $\mathrm{K} / \mathrm{kg} \mathrm{BW}$ ) (mmol K/kg BW) and age (Anderson and Langham, 1959; McNeill and Green, 1959; Baarli, Madshus, Liden, and McCall, 1961; Blahd, Cassen, and Lederer, 1962; Delwaide, Verly, Colard, and Boulenger, 1962; Remenchik and Miller, 1962; Von Dobeln, 1962; Meenely, Ball, Ferguson, Payne, Lorimer, Weiland, Rolf, and Heyssel, 1962; Woodward, Trujillo, Schuch, and Anderson, 1965; Oberhausen and Onstead, 1965; Hughes, Williams, and Smith, 1967; Allen, Anderson, and Langham, 1969).The ranges $( \pm 2 \times$ coefficient of variation) were about \pm 20 to $40 \%$. However, the usefulness of m-equiv $\mathrm{K} / \mathrm{kg} \mathrm{BW}(\mathrm{mmol} \mathrm{K} / \mathrm{kg} \mathrm{BW}$ ) as an index is limited also by the aberrations in body weight in conditions such as obesity, oedema, and starvation. It is, therefore, in circumstances of particular clinical interest that this index is least reliable. Total body potassium has been related to lean body mass, fat-free weight, or total body water and a corresponding relationship such as m-equiv $\mathrm{K}$ / $\mathrm{kg}$ LBM (mmolK/kg LBM) has been used as an index of 'normal' potassium (Woodward et al, 1965; Allen et al, 1969; Remenchik and Miller, 1962; Von Dobeln, 1962; Oberhausen and Onstead, 1965; Hughes et al, 1967). The coefficients of variation were about 6 to $9 \%$ of the mean. To permit comparison, however, lean body mass must be estimated and this can only be done indirectly from complicated body density studies (Steinkamp, Cohen, Gaffey, McKey, Bron, Siri, Sargent, and Isaacs, 1965; Durnin and Rahman, 1967) or from the measurement of total 
body water which is related to lean body mass (Pace and Rathbun, 1945). These additional measurements involve delay and cause further inconvenience to the patient. In conditions of electrolyte disturbance, when the potassium concentration in lean body mass may be abnormal, there are frequently abnormalities also of total body water. In these cases, the use of m-equiv $\mathrm{K} / \mathrm{kg} \mathrm{LBM}$ (mmol K/kg LBM) as an index will be unsatisfactory.

The relationship between total body potassium and height or height and age has, evidently, not been reported previously but the present study shows that height provides a better index than weight in respect of the standard deviations from regression, ie, about $9 \%$. Although the inclusion of age as an additional variable significantly improved the correlation in statistical terms, in practice age makes little contribution to the estimated m-equiv $\mathrm{K}$ using these relationships. Height also provides a better index than weight because in adults height will not be affected by obesity, oedema, or starvation. A corresponding reservation applies to the inclusion of lean body mass (ie height + weight) in an index in conditions such as electrolyte disorders. The novelty of this relationship to height and age and its potential usefulness because of its relative independence of clinical disorder raises the question of its physical basis. Von Dobeln (1962) indicated that lean body mass, to which total body potassium is related, could be estimated from height and skeletal parameters with a coefficient of variation of $\pm 4 \%$. Other evidence suggesting that skeletal size, and height in particular, is a significant factor in indices of 'normality' is provided by Nicholson and Zilva (1964) who found that $\mathbf{H}^{3} / \mathrm{W}$ was the most satisfactory index to describe normal values of body constituents.

When weight was included as a variable in addition to height and age, the correlation was significantly improved and the standard deviation from regression was reduced to about $7 \cdot 6 \%$. The 'normal' range was then $\pm 15 \%( \pm 2 \times$ coefficient of variation $)$. The regression equations are more strongly dependent on height than on weight as shown by the greater correlation coefficient. The coefficient of height is greater than that of weight, and, in all but one male and one female subject, the height was more than twice the weight. For example, for a $70 \mathrm{~kg}$ male of only $160 \mathrm{~cm}$ height, the contribution of the height term is more than three times that of the weight term. If the subject became oedematous to an extent of 10 litres potassium-free fluid, a situation which is scarcely compatible with life (Black, 1967), the regression would overestimate the normal body potassium by only about 240 m-equiv $\mathrm{K}$ (mmol K) which is within a single standard deviation of the non-oedematous value. However, when major aberrations in weight are suspected as a result of gross oedema, obesity, or starvation, height and age are likely to provide the more reliable index.

The two pairs of equations involving height and $\overrightarrow{\vec{s}}$ age, with and without weight, would appear there- $\overline{0}$ fore to be satisfactory, when used appropriately, in 들 a wide range of clinical disorders and particularly $\frac{\bar{m}}{2}$ those in which potassium status might be involved. The relationships are already proving of significant clinical usefulness and interest in our own experience (Boddy, King, Lindsay, Briggs, Winchester, and. Kennedy, 1972).

The estimation of lean body mass from the $\stackrel{\omega}{\omega}$ measured total body potassium is potentially valu- 응 able, especially in conditions where the use of total in body water is unreliable. The good correlation in or control subjects between lean body mass, estimated or from the height and weight relationships of Hume $\vec{N}$ and Weyers (1971), and total body potassium is 음 noteworthy. It was suggested from the chemical analysis of four cadavers (Forbes, Gallup, and $c$ Hursh, 1961) that lean body mass was consistently related to total body potassium in the ratio of 68.1 m-equiv $/ \mathrm{kg}(\mathrm{mmol} / \mathrm{kg})$ but the validity of using a single constant for both sexes was subsequently $N$ questioned (Barter and Forbes, 1963). In our own series the mean values for males and females were significantly different and were equivalent to a potassium content of lean body mass of 64.5 and $\precsim$ $57.0 \mathrm{~m}$-equiv $/ \mathrm{kg}(\mathrm{mmol} / \mathrm{kg})$ respectively. These $\stackrel{\mathbb{Q}}{\stackrel{2}{ }}$ values are lower than that of Forbes et al (1961) $\overrightarrow{\vec{P}}$ quoted above, and that of $76.2 \mathrm{~m}$-equiv $/ \mathrm{kg}(\mathrm{mmol} / \mathrm{kg})$ 을 reported in males by Hughes et al (1967) but are $\bar{T}$ comparable with the following: 65.4 in males and 58.3 in females (Allen et al, 1960), 59.3 in a popula tion of unspecified sexes (Remenchik and Miller, ? 1962), and 69.9 in males and 59.3 in females (Von 윽 Dobeln, 1962). The available evidence appears to confirm that the potassium content per $\mathrm{kg}$ lean body $\mathrm{O}$ mass is different in males and females and the mean values obtained by various workers are in fair agree- $\frac{\rho}{2}$ ment. However, the coefficient of variation found by $D$ other workers is rather greater than the values of 5.5 을. and $7.3 \%$ obtained for males and females respectively $\tilde{N}^{\circ}$ in our series.

\section{Conclusions}

Relationships have been obtained between total body 6 potassium and height or height and age which enable $\overparen{\varnothing}$ the total body potassium to be predicted in normal $\stackrel{?}{+}$ adults while avoiding the errors which may be $\frac{0}{0}$ associated with indices involving body weight. The $\frac{\vec{P}}{\mathbb{P}}$ relationships should, therefore, be of particular $\cong$ value in oedema, obesity, starvation, and other $\stackrel{\mathbb{Q}}{\varrho}$ conditions where potassium metabolism is of interest 
but aberrations in body weight might cause artefacts. When anomalous body weights are not anticipated, the standard deviation from regression can be reduced to $7.5 \%$ from about $9 \%$ by use of the regression equation relating total body potassium to weight, height, and age.

Correlation of lean body mass with total body potassium showed that the potassium content per $\mathrm{kg}$ lean body mass was significantly different between males and females. The derived regression equations had standard deviations from regression of 5.5 and $7.3 \%$ respectively, permitting an estimation of lean body mass from a measurement of total body potassium.

Thanks are due to Professor H. W. Wilson for his interest and encouragement. This work was supported by a grant from the Scottish Hospital Endowments Research Trust which is gratefully acknowledged.

\section{References}

Allen, T. H., Anderson, E. C., and Langham, W. H. (1960). Total body potassium and gross body composition in relation to age. $J$. Geront., 15, 348-357.

Anderson, E. C., and Langham, W. H. (1959). Average potassium concentration of the human body as a function of age. Science, 130, 713-714.

Baarli, J., Madshus, K., Liden, K., and McCall, R. C. (1961). Radiocaesium and potassium in Norwegians. Nature (Lond.), 191, 436-438.

Barter, J., and Forbes, G. B. (1963). Correlation of potassium-40 data with anthropometric measurements. Ann. N.Y. Acad. Sci., 110, 264-270.

Black, D. A. K. (1967). Essentials of Fluid Balance, 4th ed. Blackwell, Oxford.

Blahd, W. H., Cassen, B., and Lederer, M. (1962). Determination of total body potassium by potassium- 40 measurements in patients with muscular dystrophy and related diseases. In Whole-Body Counting: Proceedings of a Symposium Held at Vienna, 1961, International Atomic Energy Agency, Vienna, pp. 427-432.

Boddy, K. (1967). A high sensitivity shadow-shield whole body monitor with scanning-bed and tilting chair geometries, incorporated in a mobile laboratory. Brit. J. Radiol., 40, 631-637.

Boddy, K., King, P. C., Tothill, P., and Strong, J. A. (1971). Measurement of total body potassium with a shadow shield whole-body counter: calibration and errors. Phys. in Med. Biol., 16, 275-282.

Boddy, K., King, P. C., Lindsay, R. M., Briggs, J. D., Winchester, J., and Kennedy, A. C. (1972). Total body potassium in nondialysed and dialysed patients with chronic renal failure. Brit. Med. J., 1, 771.

Delwaide, P. A., Verly, G., Colard, G., and Boulenger, R. R. (1962). Determination du potassium total dans l'organisme. In Whole-Body Counting: Proceedings of a Symposium Held at Vienna, 1961, International Atomic Energy Agency, Vienna, pp. 341-350.

Durnin, J. V. G. A., and Rahaman, M. M. (1967). The assessment of the amount of fat in the human body from measurements of skin fold thickness. Brit. J. Nutr., 21, 681-689.

Forbes, G. B., Gallup, J., and Hursh, J. B. (1961). Estimation of total body fat from potassium-40 content. Science, 133, 101-102.

Forbes, G. B., and Lewis, A. M. (1956). Total sodium, potassium and chloride in adult man. J. clin. Invest., 35, 596-600.

Hughes, D., Williams, R. E., and Smith, A. H. (1967). Clinical studies on whole-body potassium content measured by gammaray spectrometry in health and disease. Clin. Sci., 32, 503-509.

Hume, R. (1966). Prediction of lean body mass from height and weight. J. clin. Path., 19, 389-391.

Hume, R., and Weyers, E. (1971). Relationship between total body water and surface area in normal and obese subjects. J. clin. Path., 24, 234-238.

McNeill, K. G., and Green, R. M. (1959). Measurements with a wholebody counter. Canad. J. Phys., 37, 683-689.

Meneely, G. R., Ball, C. O. T., Ferguson, J. L., Payne, D. D., Lorimer, A. R., Weiland, R. L., Rolf, H. L., and Heyssel, R. M. (1962). Use of computers in measuring body electrolytes by gamma spectrometry. Circulat. Res., 11, 539-548.

Nicholson, J. P., and Zilva, J. F. (1964). Body constituents and functions in relation to height and weight. Clin. Sci., 27, 97-109.

Oberhausen, E., and Onstead, C. O. (1965). Relationship of potassium content of man with age and sex: results of 10000 measurements of normal persons; factors influencing potassium content. In Radioactivity in Man, pp. 179-185. Thomas, Springfield, Illinois.

Pace, N., and Rathbun, E. N. (1945). Studies on body composition. III. The body water and chemically combined nitrogen content in relation to fat content. J. biol. Chem., 158, 685-691.

Remenchik, A. P., and Miller, C. E. (1962). The measurement of total body potassium in man and its relation to gross body composition. In Whole-Body Counting: Proceedings of a Symposium Held at Vienna, 1961, International Atomic Energy Agency, Vienna, pp. 331-339.

Steinkamp, R. C., Cohen, N. L., Gaffey, W. R., McKey, T., Bron, G., Siri, W. E., Sargent, T. W., and Isaacs, E. (1965). Measures of body fat and related factors in normal adults. II. A simple clinical method to estimate body fat and lean body mass. $J$. chron. Dis., 18, 1291-1307.

Von Dobeln, W. (1962). Discussion V.6. In Whole-Body Counting: Proceedings of a Symposium Held at Vienna, 1961, International Atomic Energy Agency, Vienna, pp. 351-352.

Woodward, K. T., Trujillo, T. T., Schuch, R. L., and Anderson, E. C. (1956). Correlation of total body potassium with body-water. Nature (Lond.), 178, 97-98. 